\title{
THE EFFECTIVENESS OF A TEACHERS' PROFESSIONAL DEVELOPMENT PROGRAM TO IMPROVE THE QUALITY OF THE PRESCHOOL ENVIRONMENT
}

\author{
Styliani Gidari ${ }^{1}$, \\ Domna - Mika Kakana ${ }^{2 i}$ \\ ${ }^{1}$ Aristotle University of Thessaloniki, \\ Faculty of Education, \\ School of Early Childhood Education, \\ Greece \\ orcid.org/0000-0001-5119-4798 \\ ${ }^{2}$ Aristotle University of Thessaloniki, \\ Faculty of Education, \\ School of Early Childhood Education, \\ Greece \\ orcid.org/0000-0002-3646-1437
}

\begin{abstract}
:
Research findings suggest that teachers' education and training is a key factor in improving the preschool quality. Teachers' qualifications can lead to high-quality preschool education and positive developmental outcomes for the children. This study examines the effectiveness of the teachers' professional development program "Upgrading the Quality of the Preschool Environment" on improving the quality of the Kindergartens. The research followed a quasi-experimental design and included 26 kindergarten teachers from 23 public Greek kindergartens, who were divided into an Experimental and a Control Group. The quality of the kindergartens was initially assessed using the ECERS-R scale and a five-month professional development program, based on this initial evaluation and on collaborative practices, was designed and implemented to the Experimental Group. Our results show that although the mean scores of quality before the implementation of the program did not differ significantly $(t=6.45$, $\mathrm{p}=.52)$, the mean scores, for the Experimental Group $(\mathrm{M}=4.71, \mathrm{SD}=.62)$ were significantly higher after the intervention $(t=4.30, p<001)$ than those of the Control Group $(\mathrm{M}=3.78, \mathrm{SD}=.37)$. The follow up evaluation one and a half years later showed the maintenance and further improvement of the results of the program in the quality of the kindergartens. Our research provides useful information that can be used in the future for the designing of professional development programs aimed at improving the quality of the preschool environment.
\end{abstract}

i Correspondence: email segidari@nured.auth.gr, dkakana@nured.auth.gr 
Keywords: preschool environment, quality improvement, teachers' professional development, evaluations of preschool quality, ECERS-R

\section{Introduction}

The importance of Early Childhood Education and Care (ECEC) quality in modern societies is undeniable, as research findings show that high quality ECEC programs can enhance the children's holistic development in the short and long term (Mashburn et al., 2008; Siraj et al., 2016).

One of the most important factors in improving the quality of the ECEC seems to be the personal, scientific and professional development (PD) of teachers (Ackerman, 2005; Manning et al., 2017). Contemporary research emphasizes the importance of teachers' professional development (PD) as a factor of support and upgrade of the teaching profession and therefore of the upgrade of the overall quality of education (Eurofound, 2015; Gibbons \& Cobb, 2017; Lazzari et al., 2013; Moiduddin et al., 2012; Sheridan, Edwards et al., 2009).

In spite of the importance of the quality of the preschool environment the few existing research data on the Greek reality show low to moderate quality of ECEC (Botsoglou \& Kakana 2015; Grammatikopoulos et al., 2014; Grammatikopoulos et al., 2017; Gregoriadis et al., 2016; Mavridou, 2013; Petrogiannis, 2002; Rentzou, 2012). It is therefore crucial to examine the possibility of improving preschool education's quality through the strengthening of teachers' PD, ensuring the children's overall development. Based on the characteristics of effective Professional development programs (PDP) and the conceptual framework of the National Professional Development Center on Inclusion (NPDCI, 2008); the collaborative teachers' PDP “Upgrading the Quality of the Preschool Environment" was designed to improve the quality of the kindergartens. The design, the implementation and the evaluation of its effectiveness on improving the quality of ECEC is the main objective of this study.

\section{Literature Review}

\subsection{The Importance of the Quality of Early Childhood Education and Care}

Research findings indicate that in modern societies, where children spend most of their day in preschool centres, the importance of early experiences for the future development and organization of a child's personality is undeniable (Camilli et al., 2010; Melhuish et al., 2015; Moiduddin et al., 2012).

However, research data show that only high quality ECEC can improve the overall development of children (Korjenevitch \& Dunifon, 2010; Sylva et al., 2011) and especially of children coming from poor and deprived socioeconomic and learning environments (Abreu-Lima et al., 2013; Bowman et al., 2001; Chambers et al., 2010; Hall et al., 2009). Quality ECEC promotes social, linguistic, emotional, and cognitive development in children in the short and long term (Sheridan, Giota et al. 2009; Sylva, et al., 2010; Sylva 
et al., 2014; Vandell et al., 2010). Students who attended quality ECEC are more likely to pursue higher academic education and that high quality supports better outcomes later in life, including market participation, poverty reduction, increased intergenerational social mobility and social inclusion (Ho et al., 2010; Lynch, 2007; Sylva et al., 2014; OECD, 2018). In contrast, low-quality programs appear to be associated with manifestations of negative impact, disobedience and aggression (Deynoot-Schaub, \& Riksen-Walraven, 2005; Sylva et al., 2011).

Quality is a concept value-based, relevant and dynamic and depends on the time, context, individuals and organizations involved (Moss \& Dahlberg, 2008; Sheridan, Giota et al., 2009). Although the quality of the preschool environment has been the subject of much research worldwide, a commonly accepted definition has not yet been reached (Hujala et al., 2012). Despite, the improbability for adopting a commonly accepted definition regarding the concept of quality in ECEC, researchers and educators worldwide agree on a number of characteristics which are classified in two general categories: structure characteristics (teacher-child ratio, number of children in the classroom, teacher education and training, financial issues, stable staff, meals, hygiene, child's safety and daily program, classroom materials) and process characteristics (stimulating, developmentally appropriate environment, positive interactions between staff and children and between peers, quality of the natural environment, activities, parental involvement) (Bonetti \& Brown, 2018; Cassidy et al., 2005; Slot, 2018).

In spite of the importance of the quality of the preschool environment the few existing research data on the Greek reality show low to moderate quality of ECEC (Gregoriadis et al., 2016; Grammatikopoulos et al., 2014; Mavridou, 2013; Petrogiannis, 2002; Rentzou, 2012). It is therefore imperative to improve the provided quality of ECEC, ensuring the children's overall development.

\subsection{Teacher's Professional Development and the Quality of Preschool Environment}

Large-scale research in recent decades has found that among a wide range of variables that appear to have an impact on ECEC's quality, teacher qualifications are recognized as one of the strongest predictors of high quality (Darling-Hammond et al., 2017; Egert et al., 2018; Manning et al., 2019; UNESCO, 2014; Whitebook, 2003). Teachers' knowledge, skills, abilities, dispositions and the way they are transformed into pedagogical and classroom practices have the greatest impact on children's learning outcomes. Research highlights teachers' development as one of the most important factors in ensuring improved quality in school (Chapman \& Harris, 2004; Fukkink \& Lont, 2007).

Teachers' PD is globally linked to the terms of school effectiveness and improvement of the quality of the provided education (Ciesielski \& Creaghead, 2020; Miller \& Bogatova, 2009). Every effort to improve school education is based on the high quality of the teacher's PD, since education policy makers have clearly realized that the upgrade of education is directly dependent on the strengthening of teachers' professional competence and skills (Guskey, 2002a; UNESCO, 2015). 
The concept of teachers' PD is characterized by complexity and polysemy regarding its perception and clarification (Avalos, 2011). According to Day (Day, 1999, p.4):

"Professional development consists of all natural learning experiences and those conscious and planned activities which are intended to be of direct or indirect benefit to the individual, group or school, which contribute, through these, to the quality of education in the classroom. It is the process by which, alone and with others, teachers review, renew and extend their commitment as change agents to the moral purpose of teaching; and by which they acquire and develop critically the knowledge, skills and emotional intelligence essential to good professional thinking, planning and practice with children, young people and colleagues throughout each phase of their teaching lives."

Kennedy (2014) described nine models of PD: Training, Deficit, Cascade, Award Bearing, Standards Based, Coaching / Mentoring, Community of Practice and Collaborative professional inquiry. Kennedy suggested that in the first three, we have the transfer of knowledge from experts to trainees (transmissive model), in the next four we have a dynamic participation of the trainees (malleable model) and finally in the Collaborative professional inquiry (transformative model) there is a combination of positive elements deriving from different models.

The concept of Community of Practice, as a PD approach, has a wide response in the field of education as it is argued that teachers learn best when they apply new knowledge in their daily practice, reflect on it and get feedback from their group (Patton \& Parker 2017). Communities of Practice are groups of people who share a concern or passion for something they do and learn how to do it better as they interact regularly (Wenger, 2006).

Research has shown that PDPs are effective when they go beyond the traditional forms of education (Darling-Hammond et al., 2017). Furthermore, PDP should refer to the connection between theory and practice, to the daily problems in the classroom and to the professional and training needs of teachers. Additional effectiveness is attributed to PDP when they actively involve teachers throughout the process (from design to evaluation), as a climate of acceptance and trust, and support of interpersonal learning and collaboration is promoted (Hunzicker, 2011; Katsarou \& Dedouli, 2008).

The recognition of the importance of teachers' PD led to a variety of studies regarding the determination of the principles and attributes that characterize effective and high quality PDP. These studies consistently identify some key elements or aspects that are associated with effective practice and improved student outcomes which are: (1) The type of professional development activities, (2) The documented practice which connects theory with practice, (3) Focus on content, (4) Focus on teacher training needs, (5) Coherence, (6) Active learning, (7) Integration into work, (8) Continuity and duration, (9) The cooperation between the teachers and (10) The training, guidance and support by experts (Coolahan, 2002; Darling-Hammond et al., 2017; Desimone, 2011; Hunzicker, 2011; van Driel et al., 2012). 
In sum, providing high quality professional development is a central point of every effort seeking to improve the quality of education. We can say that the involvement of teachers in prolonged, flexible, individualized and collaborative PDPs, commencing from the needs of teachers, are characterized by coherence and focus on amplifying their knowledge of both content and pedagogy, resulting in long-term and consistent learning outcomes (Knight, 2002).

\subsection{The Present Study}

In the Greek reality there is a shortage of studies on organized efforts to improve the quality of kindergartens through PDP for teachers. The aim of the present study was to examine the impact of a teachers' PDP "Upgrading the Quality of the Preschool Environment" on improving the quality of ECEC.

Our research questions are formed as follows:

Research question 1: Will the kindergartens of the group that will participate in the program show an improvement in their quality, which will be statistically more significant compared to that of the Control Group?

Research question 2: Which aspects of quality will show the greatest improvement?

Research question 3: Will any improvement of the quality of the kindergartens be maintained one and a half year after the implementation of the program?

\section{Material and Methods}

The research followed a quasi-experimental design, with an Experimental Group (EG) and a Control Group (CG), to examine the impact of the PDP on improving the quality of kindergartens.

\subsection{Sample}

The sample comprised of 26 Kindergarten teachers ( 1 man and 25 women), working in 23 Greek public Kindergartens. Teachers were divided into an EG (14 teachers-11 kindergarten classes), which took part in the PDP and in a CG (12 teachers - 12 kindergarten classes). Follow-up data were available for 8 from the 11 Kindergarten classes of the EG. To avoid the problem of contamination, we have ensured that EG and CG schools were geographically distant.

The survey was approved by the Institute of Educational Policy (Act no. 28 / 10-72017 of the Board of IEP). All aspects of ethics were taken into account in the present study. All participants were informed about the purpose, procedure and duration of the research by letter and agreed to sign their participation.

\subsection{Instruments}

Quality was assessed by the Early Childhood Environment Rating Scale-Revised (ECERS-R, Harms, Clifford \& Cryer, 1998, Greek edition, Ed., Botsoglou \& Kakana, 2013). 
ECERS-R is an observational measure used to rate the global quality of early childhood educational environments. Is comprised of 470 indicators, organized into 43 items under seven subscales: Space and Furnishings, Personal Care, Language-Reasoning, Activities, Interactions, Program Structure, and Parents and Staff. Items were scored by a trained observer on a 7 -point scale, where $1=$ inadequate, $3=$ minimal, $5=$ good and $7=$ excellent.

The ECERS-R is one of the preschool quality's measuring tools that have been used most often both internationally and in Greece in evaluations of the quality of preschool environments. It focuses on the perspective - experience of the child and on the evaluation of the preschool environment as a learning environment and not on the evaluation of individual teachers or students (Sheridan, Giota, et al., 2009).

\subsection{Procedures}

The research was completed in 3 years and included four stages:

In the first stage, the initial evaluation of the quality of the kindergartens was carried out using the ECERS-R scale. Teachers filled in the initial Teachers Questionnaire, used to detect their training needs.

In the second stage, the program "Upgrading the quality of the preschool environment" was designed and implemented, taking into account the existing level of quality of the kindergartens of the first stage and the training needs of the teachers. The 5-month PDP has been co-designed by the researcher, the external lecturers and the teachers and was run in collaboration with the Aristotle University of Thessaloniki.

In the third stage of the study, by the end of the PDP, the quality was re-evaluated using the ECERS-R. A comparison of the measurements before and after the intervention for the EG and the CG was made.

In the fourth stage, one and a half year after the end of the delivery of the PDP, a follow-up quality evaluation of the kindergartens of the EG was carried out using the ECERS-R scale, in order to determine the degree of maintenance of the results of the program.

\subsection{Teachers' Professional Development Program “Upgrading the Quality of the Preschool Environment"}

The PDP 'Upgrading the quality of the preschool environment' aimed at supporting teachers on a theoretical, practical and reflectional level in order for them to critically review and enhance or improve their practices and therefore the level of quality of their Kindergartens and by extension of their students' outcomes.

The program's design took into consideration the results of the participating preschools' quality evaluation, which was conducted with the use of ECES-R scale (Harms, Clifford \& Cryer, 2013), and teachers' training needs, as were detected through a questionnaire. The design and implementation of the PDP was based on the theoretical and research literature on the characteristics of effective PDPs and the conceptual framework of NPDCI (2008). This framework emphasises three key components of PDP: the learners (who), the content (what) and the educational methods and approaches 
employed (how), with a contextual variables (Policies, resources, organizational structures, access, outreach, and evaluation) (Figure 1).

The PDP was flexible and was codesigned by the authors, the participating teachers and external lecturers (University staff of AUTh and psychologists). The content of the lectures, was given in a dialogue format, was flexible and continuously changing depending on the questions raised by the teachers, their interests and the progress of the program.

Eight meetings were organized in a 5-month period, outside the school schedule. Each meeting lasted 2.30-3 hours and was comprised of a brief introduction, in the form of dialogue, during which the teachers participated by expressing their viewpoints and presenting their pedagogical practices. At the beginning of every meeting, a reflection took place, where participants shared and analyzed their experiences regarding their efforts to implement in the classroom what was discussed in the previous meeting. During the programme, the researcher had a coordinating, supporting and facilitating role. The concepts that were discussed and the supporting material that was administered regarded the:

- Program quality standards and the ECERS-R criteria,

- Measurement and documentation of the quality of preschool environment,

- Classroom management,

- Physical space and educational processes,

- Verbal interactions in kindergarten,

- Collaborative approach,

- Collaboration - communication with parents,

- Program structure - planning and organization of activities.

At the end of the PDP, the quality of the participating kindergartens was reevaluated with the ECERS-R scale, in order to make a comparison between the EG and the CG as well as between the measurements before and after the intervention and finally to evaluate the effectiveness of the PDP to improve the quality of kindergartens. 


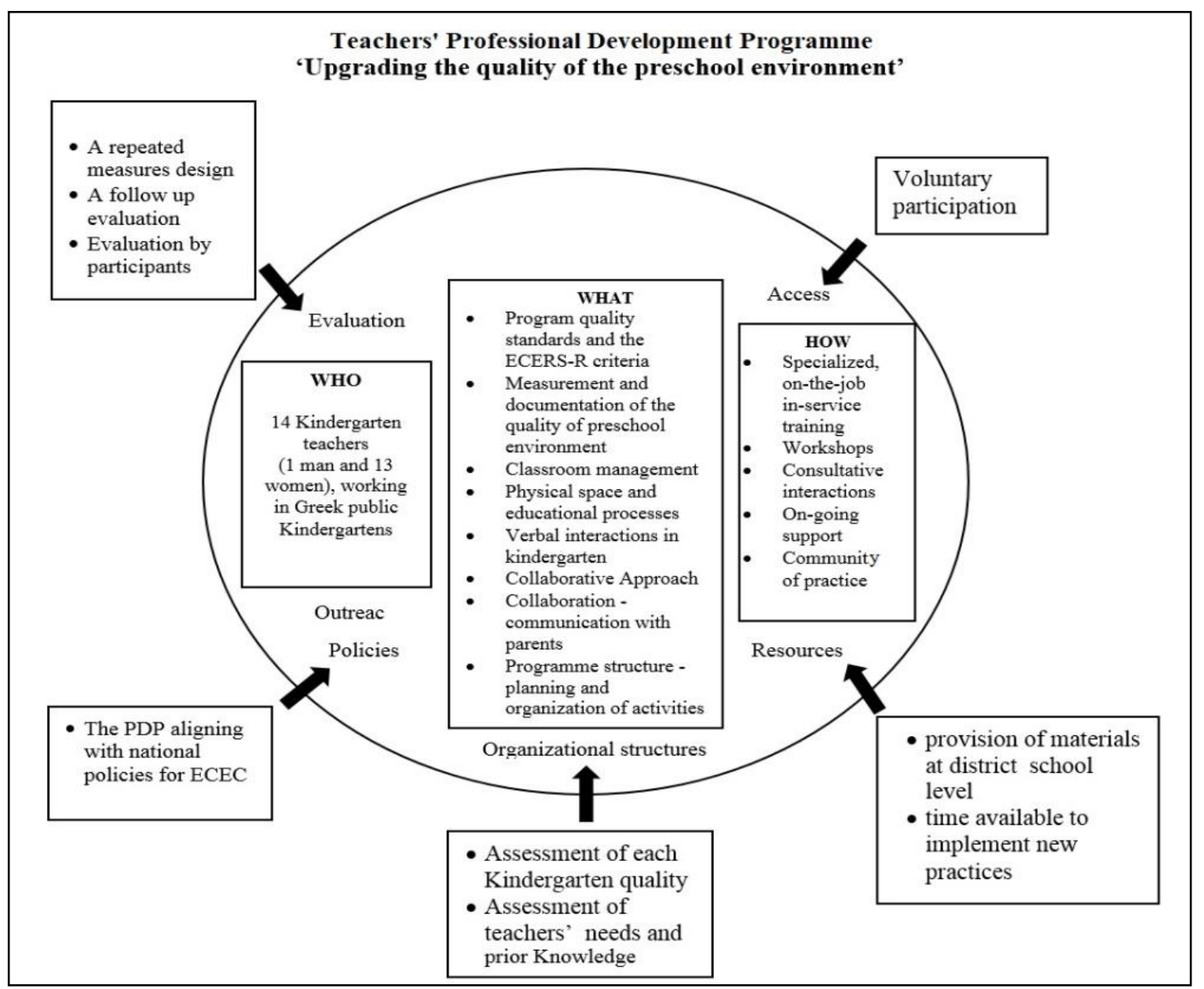

Figure 1: The framework of the PDP 'Upgrading the quality of the preschool environment', adapted from the conceptual framework of NPDCI (2008)

\section{Results}

\subsection{Differences in Classroom Quality between the Groups, Before the Implementation of the PDP}

Our research examines the changes that will occur in the quality of the preschool environment in the EG compared to the CG, as a result of the implementation of the PDP. It is therefore necessary to investigate whether the two groups differ in the level of their quality before the implementation of the program, so that any changes that occur after the implementation can be attributed to the intervention and not to the initial differences between groups. In order to determine whether the two groups, EG and CG, are equivalent to the quality of the preschool environment, an independent t-test was initially taken by the participants. The results show that the mean scores of the total scale and sub-scales of ECERS-R, for the EG and the CG, before the intervention did not differ significantly from each other: ECERS-R $(t=.64, p=.525)$, Space and furnishings $(t=-1.30$, $\mathrm{p}=.207)$, Daily personal care $(\mathrm{t}=.85, \mathrm{p}=.402)$, Language-Thought $(\mathrm{t}=.93, \mathrm{p}=.364)$, Activities $(t=1.57, p=.131)$, Interaction $(t=1.29, p=.210)$, Program structure $(t=.20, p=.840)$, Parents and teaching staff $(\mathrm{t}=1.60, \mathrm{p}=.123)$ (Table 1$)$. 
Table 1: Comparisons of ECERS-R between EG and CG in pre-test

\begin{tabular}{|c|c|c|c|c|c|}
\hline & \multirow{2}{*}{$\begin{array}{c}\text { Experimental } \\
(n=11)\end{array}$} & \multirow{2}{*}{$\begin{array}{c}\text { Control } \\
(n=12)\end{array}$} & \multirow[t]{3}{*}{$t$} & \multirow[t]{3}{*}{$d f$} & \multirow[t]{3}{*}{$p$} \\
\hline & & & & & \\
\hline & M(SD) & M(SD) & & & \\
\hline Space and Furnishings & $3.70(.912)$ & $4.17(.829)$ & -1.30 & 21 & .207 \\
\hline Personal Care Routines & $2.73(.800)$ & $2.47(.662)$ & .85 & 21 & .402 \\
\hline Language-Reasoning & $4.70(.269)$ & $4.54(.520)$ & .92 & 21 & .364 \\
\hline Activities & $3.61(.513)$ & $3.26(.554)$ & 1.57 & 21 & .131 \\
\hline Interaction & $5.76(.307)$ & $5.58(.356)$ & 1.29 & 21 & .210 \\
\hline Program structure & $4.18(.544)$ & $4.13(.459)$ & .20 & 21 & .840 \\
\hline Parents and Staff & $2.06(.361)$ & $1.85(.233)$ & 1.60 & 21 & .123 \\
\hline ECERS-R & $3.82(.393)$ & $3.72(.379)$ & .64 & 21 & .525 \\
\hline
\end{tabular}

Research Question 1: Differences in Classroom Quality Between the Groups, After the Implementation of the PD.

To determine whether the PDP resulted in a statistically significant improvement in the quality of the kindergartens of the EG compared to that of the CG, a repeatedmeasure univariate analysis of variance (ANOVA) was performed. For both, the overall scale and the ECERS-R subscales a significant Group (EG and CG) X Time (pre-test and pos-test) interaction occurred: ECERS-R $\left(F_{1,21}=72.92, p=.000, \eta_{\mathrm{p}}{ }^{2}=.78\right)$, Space and Furnishings $\left(F_{1,21}=32.01, p<.000, \eta_{\mathrm{p}}{ }^{2}=.60\right)$, Daily personal care $\left(F_{1,21}=24.38, p<.000\right.$, $\left.\eta_{\mathrm{p}}{ }^{2}=.54\right)$, Language-Thought $\left(F_{1,21}=17.18, p<.000, \eta_{\mathrm{p}}{ }^{2}=.47\right)$, Activities $\left(F_{1,21}=15.18, p=.001\right.$, $\left.\eta_{\mathrm{p}}{ }^{2}=.43\right)$, Interaction $\left(F_{1,21}=6.17, p=.021, \eta_{\mathrm{p}}{ }^{2}=.25\right)$, Program structure $\left(F_{1,21}=15.92, p=.001, \eta_{\mathrm{p}}{ }^{2}\right.$ $=.45)$, Parents and teachers $\left(F_{1,21}=3.06, p=.095, \eta_{\mathrm{p}}{ }^{2}=.12\right)$ (Figure 2).

Paired $t$-tests (Figure 3), which compared the pre-test and post-test scores, showed a significant improvement in the overall scale and the subscales of ECERS-R, for the EG: ECERS- $\mathrm{R}, \mathrm{t}=-9.58, \mathrm{p}<.001$; Space and furnishings, $\mathrm{t}=6.5, \mathrm{p}<.001$; Daily personal care, $\mathrm{t}$ $=-8.104, \mathrm{p}<.001$; Language- Thought, $\mathrm{t}=-5.27, \mathrm{p}<.001$; Activities, $\mathrm{t}=-5.34, \mathrm{p}<.001$; Interaction, $\mathrm{t}=-3.70, \mathrm{p}<.01$ and Program structure, $\mathrm{t}=-5.64, \mathrm{p}<.001$. The Parents and teachers subscale did not change after the intervention. There was no statistically significant difference in the pre-test and post-test scores for the CG on the overall scale and the subscales of ECSC-R: ECERS-R, $\mathrm{t}=4.32 .12, \mathrm{p}=.670$; Space and Furnishings, $\mathrm{t}=$ 1.30, $\mathrm{p}=.207$; Daily personal care, $\mathrm{t}=.85, \mathrm{p}=.402$; Language-Thought, $\mathrm{t}=.92, \mathrm{p}=.364$; Activities, $\mathrm{t}=1.57, \mathrm{p}=.13$; Interaction, $\mathrm{t}=1.29, \mathrm{p}=.210$; Program structure, $\mathrm{t}=.20, \mathrm{p}=.840$. The Parents and teachers' subscale did not change after the intervention. 


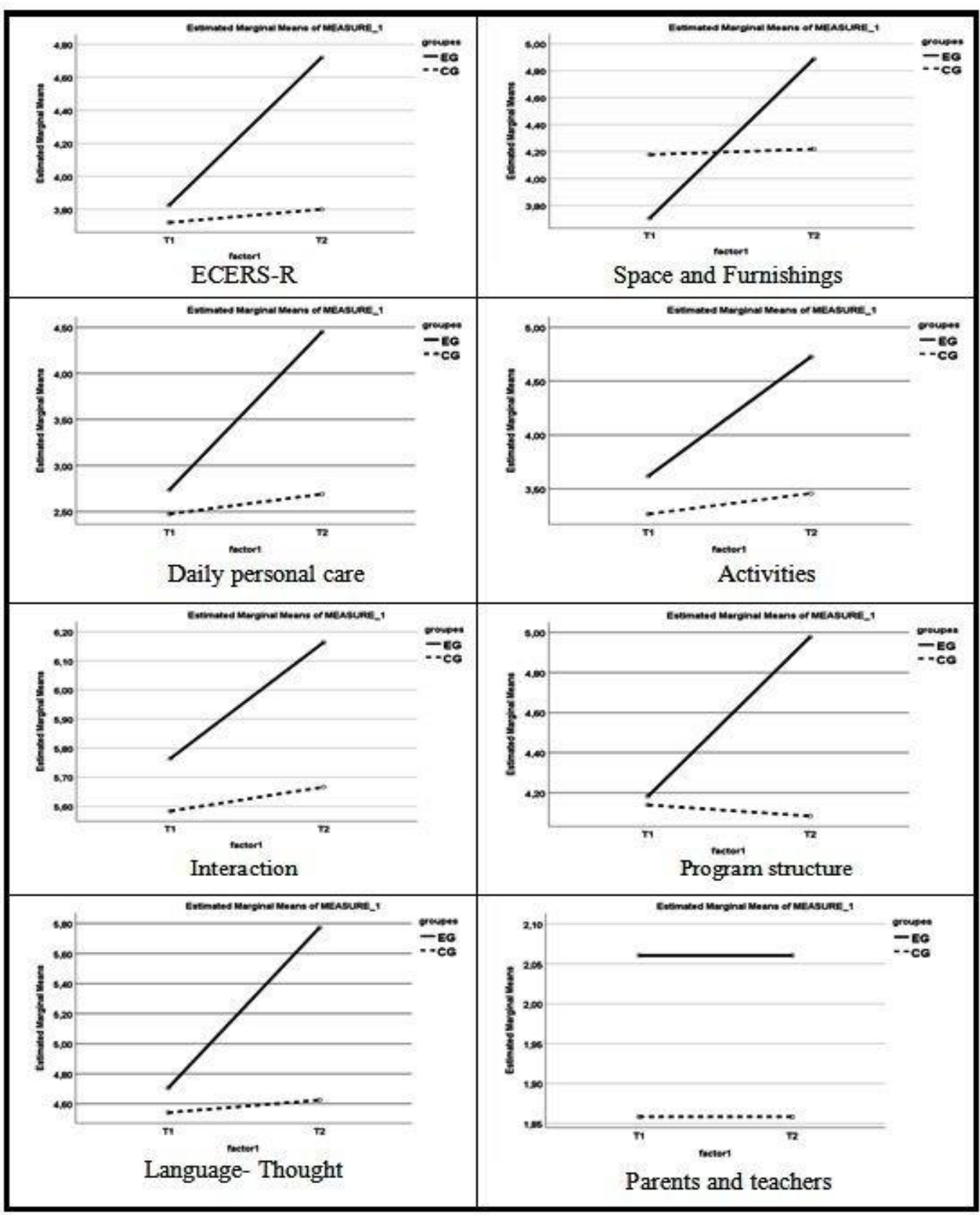

Figure 2: Comparison of the Experimental and the Control groups' pre and post-test on the ECERS-R

The independent $t$-test showed that after the intervention, kindergartens of the EG received significantly higher ratings on the overall scale and the subscales of ECERS-R, compared to that of the CG: ECERS-R, $\mathrm{t}=4.30, \mathrm{p}<.001$; Daily personal care, $\mathrm{t}=4.20, \mathrm{p}<.001$; Language-Thought, $\mathrm{t}=4.72, \mathrm{p}<.001$; Activities, $\mathrm{t}=3.77, \mathrm{p}<.001$; Interaction, $\mathrm{t}=2.69, \mathrm{p}<.05$; Program structure, $\mathrm{t}=3.63, \mathrm{p}<.01$. Only the mean scores of the subscales Space and Furnishings, $\mathrm{t}=1.67, \mathrm{p}=.108$ and Parents and teachers, $\mathrm{t}=1.60, \mathrm{p}=.123$, did not show a significant difference between the groups after the implementation of the PDP (Table 2). 


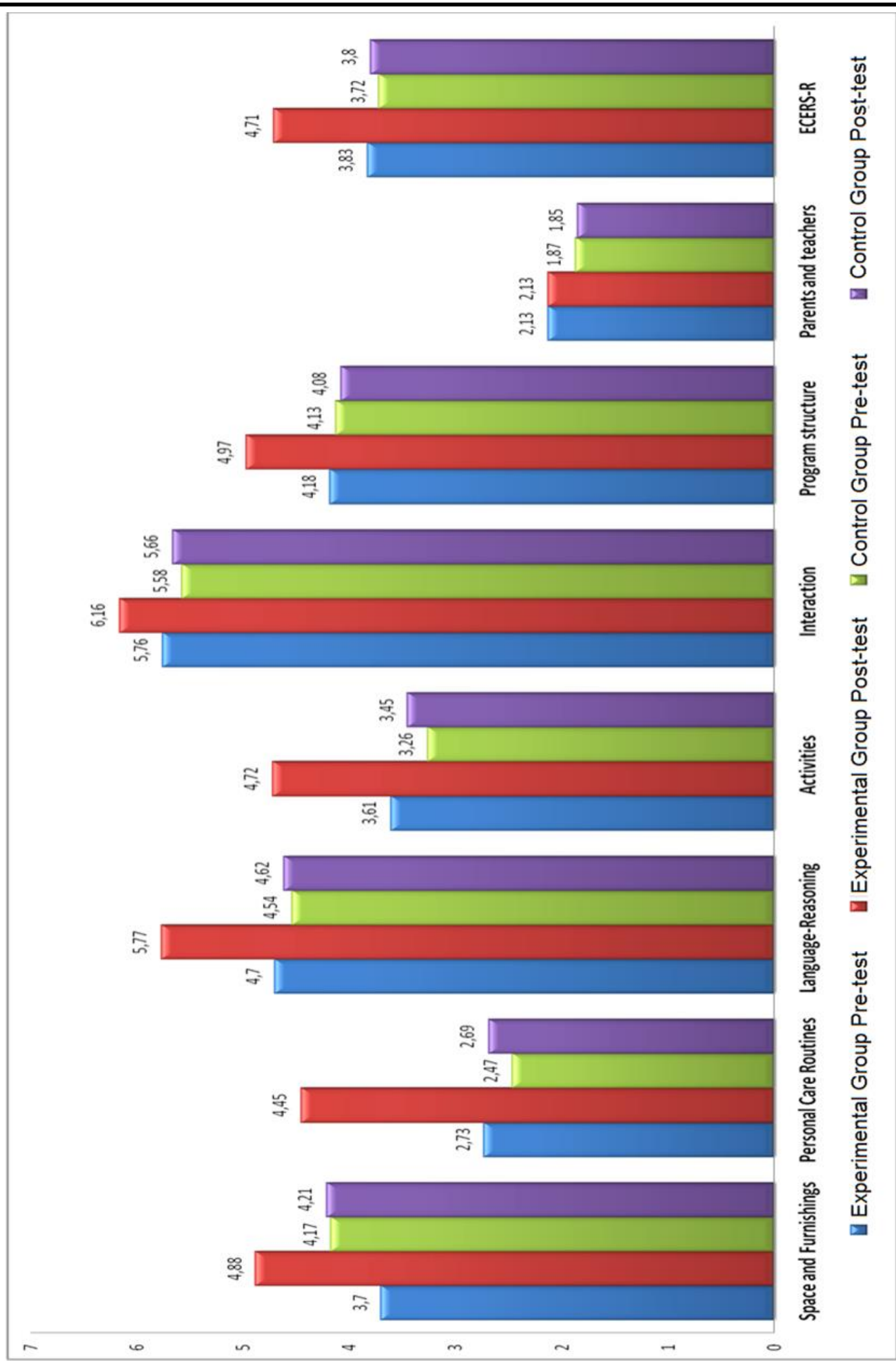

Figure 3: Graphical representation of the mean scores of the ECERS-R scale and its subscales at the pre and post-test for the EG and the CG 
Table 2: Comparisons of ECERS-R between EG and CG in post-test

\begin{tabular}{|c|c|c|c|c|c|}
\hline & \multirow{2}{*}{$\begin{array}{c}\text { Experimental } \\
(\mathrm{n}=11)\end{array}$} & \multirow{2}{*}{$\begin{array}{c}\text { Control } \\
(n=12)\end{array}$} & \multirow[t]{3}{*}{$t$} & \multirow[t]{3}{*}{$d f$} & \multirow[t]{3}{*}{$p$} \\
\hline & & & & & \\
\hline & M (SD) & M (SD) & & & \\
\hline Space and Furnishings & $4.88(1.07)$ & $4.21(.83)$ & 1.67 & 21 & .108 \\
\hline Personal Care Routine & $4.45(1.05)$ & $2.69(.96)$ & 4.20 & 21 & .000 \\
\hline Language-Reasoning & $5.77(.56)$ & $4.62(.60)$ & 4.72 & 21 & .000 \\
\hline Activities & $4.72(.98)$ & $3.45(.60)$ & 3.77 & 21 & .001 \\
\hline Interaction & $6.16(.38)$ & $5.66(.49)$ & 2.69 & 21 & .013 \\
\hline Program structure & $4.97(.79)$ & $4.08(.32)$ & 3.63 & 21 & .002 \\
\hline Parents and Staff & $2.06(.36)$ & $1.85(.23)$ & 1.60 & 21 & .123 \\
\hline ECERS-R & $4.71(.63)$ & $3.80(.38)$ & -4.30 & 21 & .000 \\
\hline $\mathrm{p}<.05$ & & & & & \\
\hline
\end{tabular}

Research Question 2: Aspects of Quality that Showed the Greatest Improvement.

To identify the quality aspects that showed the greatest improvement, we calculated the difference of the mean scores of the overall ECERS-R scale and its subscales' scores in the pre-test and the post-test, for the EG. As we observe in Table 3, the areas that show the greatest improvement are the Space and furnishings (Difference in means $=1.18$ ), the Daily Personal Care (Difference in means = 1.72), the Activities (Difference in means $=1.11$ ), the Language-Thought (Difference in means =1.07), and the overall ECERS-R scale (Difference in means $=.86$ ). A smaller but statistically significant improvement was observed in the sub-scales Structure of the program (Difference in means $=.70$ ), and Interaction (Difference in means $=.40$ ). Finally, the Parents and teachers' subscale showed no change.

Research Question 3: Maintaining the results of the program.

In order to examine the maintenance of the results of the PDP in the improvement of the quality of the EG' kindergartens, we carried out a series of Paired $t$-tests (Table 4). Results showed that there was no statistically significant difference between the measurement at the end of the PDP and one and a half years after the intervention for: the ECERS-R scale, $\mathrm{t}=-1.68, \mathrm{p}=.136$; the Space and Furnishing $\mathrm{t}=-.26, \mathrm{p}=.801$; the Daily Personal Care, $\mathrm{t}=-5.29, \mathrm{p}=.001$; the Language-Thought $\mathrm{t}=-.09, \mathrm{p}=.928$; the Activities subscale, $t=-.61, p=.559$; the Interaction subscale $t=-.14, p=.883$; the Program Structure $\mathrm{t}=-.50, \mathrm{p}=.628$. The Parents and teachers subscale did not change between the measurement at the end of the PDP and one and a half years after the intervention, $t=-$ $1.00, \mathrm{p}=.351)$. 
Table 3: Descriptives and differences between mean scores at pre and post-test of the ECERS-R and its subscales for the EG

\begin{tabular}{|l|l|c|c|c|c|}
\hline & \multicolumn{2}{|c|}{ Pre-test } & \multicolumn{2}{c|}{ Post-test } & \\
\hline & $\mathbf{M}$ & SD & $\mathbf{M}$ & SD & Differences between mean scores \\
\hline Space and Furnishings & 3.70 & .91 & 4.88 & 1.07 & 1.18 \\
\hline Personal Care Routines & 2.73 & .80 & 4.45 & 1.05 & 1.72 \\
\hline Language-Reasoning & 4.70 & .26 & 5.77 & .56 & 1.07 \\
\hline Activities & 3.61 & .51 & 4.72 & .98 & 1.11 \\
\hline Interaction & 5.76 & .30 & 6.16 & .37 & .40 \\
\hline Program structure & 4.18 & .54 & 4.97 & .78 & .79 \\
\hline Parents and Staff & 2.13 & .91 & 2.13 & .91 & 0 \\
\hline ECERS-R & 3.82 & .39 & 4.71 & .62 & .89 \\
\hline
\end{tabular}

Table 4: Comparisons of ECERS-R between the measurement at the end of the PDP and the follow up measurement for experimental group

\begin{tabular}{|l|c|c|c|c|c|}
\hline & $\begin{array}{c}\text { Post-test } \\
\text { M(SD) }\end{array}$ & $\begin{array}{c}\text { Follow up } \\
\text { M(SD) }\end{array}$ & $\boldsymbol{t}$ & $d f$ & $p$ \\
\hline Space and Furnishings & $5.06(.90)$ & $5.14(1.13)$ & -.26 & 7 & .801 \\
\hline Personal Care Routine & $4.37(1.22)$ & $5.52(.86)$ & -5.29 & 7 & .001 \\
\hline Language-Reasoning & $5.78(.66)$ & $5.81(.97)$ & -.09 & 7 & .928 \\
\hline Activities & $4.82(1.14)$ & $4.75(1.07)$ & -.61 & 7 & .559 \\
\hline Interaction & $6.22(.42)$ & $6.25(.66)$ & -.14 & 7 & .883 \\
\hline Program structure & $5.01(.91)$ & $5.15(.77)$ & -.50 & 7 & .628 \\
\hline Parents and Staff & $2.02(.41)$ & $2.08(.41)$ & -1.00 & 7 & .351 \\
\hline ECERS-R & $4.75(.72)$ & $4.96(.73)$ & -1.68 & 7 & .136 \\
\hline p $<.05$ & & & & \\
\hline
\end{tabular}

\section{Discussion}

The aim of the present study was to explore the possibility of improving the existing quality of kindergartens by enhancing the professional development of teachers through a PDP.

The results of the pre-test in kindergartens revealed low to moderate quality, consistent with findings in Greece and internationally (Gregoriadis et al., 2016; Kingston, 2017; Mavridou, 2013; Botsoglou \& Kakana, 2015; Petrogiannis, 2010, Rentzou, 2012). The subscale Routines and Personal Care is characterized by the lowest quality, while the subscale Interactions presents the highest score. Teachers probably attribute great importance to early interactions, which are very important for infant development (Hamre et al., 2014). Issues of personal hygiene and hygiene conditions present problems, teacher-parent relationships need to be developed, and the provision for teacher needs and PD is almost non-existent.

Following the implementation of the PDP, the data collected, clearly support the positive impact of the program on kindergartens' practices. Our results showed a pattern of significant improvements in the level of quality in the Kindergartens of the EG. On the other hand, the CG kindergartens showed almost no change in their quality level between 
the two measurements. The improvements reflected the PDP itself, the targeted content and the discussions it included (Kingston, 2017; Peleman et al, 2018; Sheridan, 2001).

At the subscales level, the most significant improvement from pre-test to post-test for the EG was presented at the subscales Daily Personal Care, Space and Furnishing and Activities. This is not surprising, as it is generally accepted that the quality aspects that are basic and have a strong focus on resources, require minimal changes for improvement (e.g. with the addition of soft toys, backs on the benches of the 'circle', hanging children's works at eye level, adding and organizing material in the corners of activities, enriching and organizing the library, etc.). However, the quality of sub-scales such as LanguageThinking, Interaction and Program Structure has also improved. These sub-scales are related to the knowledge and the role of teachers in supporting children's learning and emphasize the acquisition of higher class skills (e.g. encouraging communication, informal use of language, child-staff interaction, small group work), which may be more complex and take longer to change (Roach, Riley et al., 2005; Siraj et al., 2016).

No difference or improvement was reported in the Parents and Teachers subscale. This is partly due to the fact that in the Greek educational system, there is no institutional provision for parents to participate in the planning and evaluation of the school's educational work. In addition, issues related to the needs, professional development and quality assessment of kindergarten teachers, which are mainly responsible for the very low score of the subscale, cannot be changed arbitrarily by teachers. In the Greek kindergarten there is an almost complete absence of provision for the personal and PD of teachers, as well as for their quality assessment.

In the results of the CG, we observe only slight improvements in the subscales and the overall ECERS-R, while the subscale Structure of the program showed a slight decrease. The Parents and Staff subscale did not show any change. It is noteworthy that without encouragement and support, teachers do not make changes neither in the physical environment of their classroom nor in their teaching practices during the school year.

Fundamental to the success of a PDP is for the trainees to gain the ability to continue the process of quality improvement on their own. The reassessment of the EG Kindergartens' quality a year and a half later showed that not only were the positive results maintained in the improvement of the quality, but a small improvement in most of the subscales and in the overall ECERS-R scale, was also noticed. Their constant support and cooperation with the researcher, whenever requested, also contributed to this direction. This confirms the results of other research showing that it takes time for experimentation and reflection on their practice in order for teachers to adopt them (Garet et al., 2001).

The program seems to have successfully achieved every single aim, mostly because the researchers took into consideration the participants' needs and suggestions, their strong points and the parts in which they needed support, as they derived from the evaluation of their schools' quality. A training program is efficient when it is targeted, embedded and focuses on the satisfaction of teachers' particular needs and in the 
treatment of the specific requirements of each school (Schachter, 2015; Sheridan, Edwards et al., 2009; Tsafos, n.d.). By enhancing the teachers' reflection on both individual and group levels, PD activities enable teachers to enhance their skills and identify areas for improvement in their daily practices (Peeters, et al., 2014). Moreover, teachers participated in the program voluntarily and had an active role in the design of the program, which reinforced their commitment towards the program and enhanced their motives to learn (Hunzicker, 2011).

In addition, the program managed to combine theory and practice and connect the theoretical knowledge with the everyday practice at school. Teachers think that professional development is important, and that learning becomes authentic when there is a link between the learning experience and the everyday practices and duties at school (Fokiali \& Kaila, 2005).

Another element of the program that contributed to its effectiveness was its duration. Many studies show that a significant amount of time (both time span and contact hours) is necessary for professional development to be effective (Desimone, 2011. Yoon et al., 2007). According to Garet et al. (2001), the duration of PD activities is important in two ways: Firstly, a longer duration is more likely to offer teachers the opportunity for in-depth discussion about the content, students' perceptions and misunderstandings and pedagogical strategies, and secondly, long-term PD activities are more likely to facilitate teachers to try out new classroom practices and receive feedback on their teaching.

Another factor that contributed to the program's success was the development of a specific collaborative culture and the shift to a community of practice. Over a period of time, this created an environment of equality, security and comfort that allowed participants to engage in interactions with one another and with their lecturers, to share their problems, experiences, ideas and opinions, to accept feedback and work together in order to find solutions (Darling-Hammond et al., 2017; Hunzicker, 2011; Lave \& Wenger, 1991; Lieberman \& Pointer-Mace, 2008).

\section{Recommendations}

The Greek educational system is largely centralized and bureaucratic, leaving little space for self-action and initiatives at the district-school level. As a result, teacher training is based on traditional models, has an academic and theoretical profile and is designed and implemented centrally through bureaucratic procedures, while teachers have a passive role (Karras \& Oikonomides, 2015). Our research provides some remarkable evidence for the design of a small scale effective kindergarten teachers' PDP, which is organized locally, taking into account the special needs of specific schools and teachers. Our findings present the characteristics of an effective PDP as defined by the contemporary bibliography and can add to the existing knowledge about the design and implementation of effective teacher PDP. They could be taken into account by the designers of the teachers' PDP with the aim of improving teachers' professional growth 
and quality of the classroom and enhancing the overall development of children. Future studies should also, further investigate the contents, methods and delivery of the PDP with a view to developing typologies that can effectively improve the quality of ECEC. Future research could also examine students' outcomes as a result of the improvement of the kindergartens' quality deriving from the implementation of similar PDPs.

\section{Conclusion}

Our research aimed mainly at the design, implementation and evaluation of a PDP aimed to develop the quality of the preschool environment. Although the small number of participants and the specialized content of the program do not allow us to generalize our results, they however contribute to the development of evidence-based PDP for Kindergarten teachers.

The focalized PDP that was implemented showed that it can bring about significant improvement in the quality of the participating kindergartens in a consistent and sustainable way. Our data supported the efficiency of the program and provided with feedback for its improvement and continuance. Our findings demonstrate that the PDP was designed, implemented and evaluated using the best practices from adult education and the communities of practice, aiming to meet the initial quality and needs of the settings for which the PD is designed, and therefore affected greatly teachers' learning and practice.

Our research findings suggest that the conceptual framework of the NPDCI constitutes an effective context for the development of such programs and contribute to the research literature by providing empirical data for the synthesis of teacher PD frameworks that will effectively support them in order to improve their PD and consequently the quality of ECEC.

\section{Conflict of Interest Statement}

The authors declare no conflicts of interests.

\section{About the Authors}

Styliani Gidari, is a PhD candidate of the School of Early Childhood Education, Aristotle University of Thessaloniki. She works as a kindergarten teacher in a public kindergarten in Greece. Her research interests include the quality in education, the professional development of teachers, educational evaluation, history of education, and the informatics in education. https://orcid.org/0000-0001-5119-4798

Domna (Mika) Kakana, is the Dean of the Faculty of Education at the Aristotle University of Thessaloniki and Professor in Educational Sciences at the School of Early Childhood Education (Auth). She has over 170 publications, 10 books (6 editing), and articles in Greek and English journals, book chapters and in conference proceedings. Her recent research interest focuses on the development of contemporary environments of teaching and learning in education, such as collaborative and/or cooperative, at the 
improvement of the quality of the pedagogical environment and school space, at the curriculum design and the new didactical approach such as differentiated instruction, at the learning and teaching through pay, at the pre-service and in-service teachers' education and professional development, at the educational evaluation and selfevaluation of school units, and at the effects of economic crisis on education and social inequalities due to Covid-19. https://orcid.org/0000-0002-3646-1437

\section{References}

Abreu-Lima I, Leal T, Cadima J, Gamelas A M, 2013. Predicting child outcomes from preschool quality in Portugal. European Journal of Psychology of Education 28: 399-420.

Ackerman DJ, 2005. Getting Teachers from Here to There: Examining Issues Related to an Early Care and Education Teacher Policy. Early Childhood Research and Practice 7(1). Google scholar

Avalos B, 2011. Teacher professional development in Teaching and Teacher Education over ten years. Teaching and Teacher Education 27(1): 10-20. Google scholar

Azzi-Lessing L, 2009. Quality support infrastructure in early childhood: Still (mostly) missing. Early Childhood Research and Practice 11(1). http://ecrp.uiuc.edu/v11n1/azzi.html

Bonetti S, Brown K, 2018. Structural elements of quality early years provision: A review of the evidence. London: Education Policy Institute. https://dera.ioe.ac.uk/32065/1/Early-years-structural-quality-review EPI.pdf

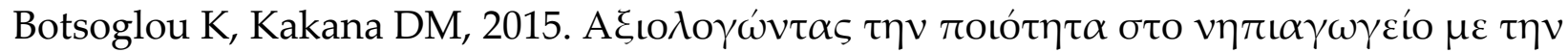

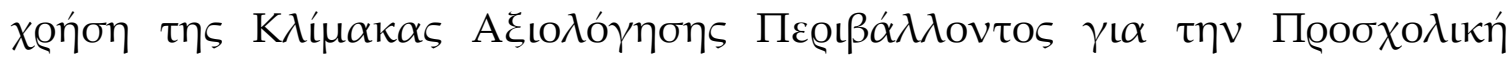

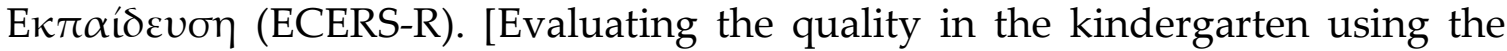
Environmental Assessment Scale for Preschool Education (ECERS-R)]. Dialogues. Theory and Practice in Education Sciences 1: 4-14. https://doi.org/10.12681/dial.10

Bowman BT, Donovan MS, Burns MS. (Eds.) (2001). Eager to learn: Educating our preschoolers, Washington, DC: National Academy Press. Google Scholar

Camilli G, Vargas S, Ryan S, Barnett WS, 2010. Meta-analysis of the effects of early education interventions on cognitive and social development. The Teachers College Record 112 (3): 579-620. https://psycnet.apa.org/record/2011-06375-001

Cassidy D, Hestenes L, Hansen J, Hedge A, Shim J, Hestenes S, 2005. Revisiting the two faces of child care quality: Structure and process. Early Education and Development 16 (4): 505-520.

Chambers B, Cheung AC, Slavin RE, Smith D, Laurenzano M, 2010. Effective early childhood education programs: A systematic review. Baltimore, MD: Johns Hopkins University, Center for Research and Reform in Education. Google Scholar 
Chapman C, Harris A, 2004. Improving schools in difficult and challenging contexts: strategies for improvement, Educational Research 46 (3): 219-228. https://doi.org/10.1080/0013188042000277296

Ciesielski EJM, Creaghead NA, 2020. The Effectiveness of Professional Development on the Phonological Awareness Outcomes of Preschool Children: A Systematic Review. Literacy Research and Instruction 59 (2): 121-147. DOI: 10.1080/19388071.2019.1710785.

Coolahan J, 2002. Teacher education and the teaching career in an era of lifelong Learning. OECD Education Working Paper, Number 2 (Paris, Education Directorate, OECD). https://core.ac.uk/download/pdf/143612882.pdf

Darling-Hammond L, Hyler ME, Gardner M, 2017. Effective Teacher Professional Development, Palo Alto, CA: Learning Policy Institute.

Day C, 1999. Developing Teachers: The Challenges of Lifelong Learning, London, Falmer Press. https://files.eric.ed.gov/fulltext/ED434878.pdf

Desimone LM, 2011. A primer on effective professional development. Phi Delta Kappan 92: 68-71.

Deynoot-Schaub MJG, Riksen-Walraven JM, 2005. Childcare under pressure: The quality of Dutch centers in 1995 and 2001. The Journal of Genetic Psychology 66 (3): 280296.

Egert F, Fukkink R, Eckhardt AG, 2018. Impact of in-service professional development programs for early childhood teachers on quality ratings and child outcomes: A meta-analysis. Review of Educational Research 88(3): 401-433. https://doi.org/10.3102/0034654317751918

Eurofound, 2015. Early Childhood Care: Working conditions, training and quality of services - A systematic review. Luxembourg: Publications Office of the European Union. Google scholar

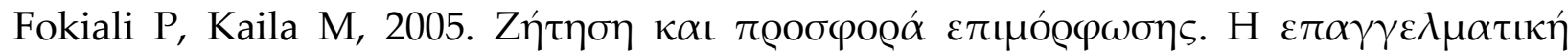

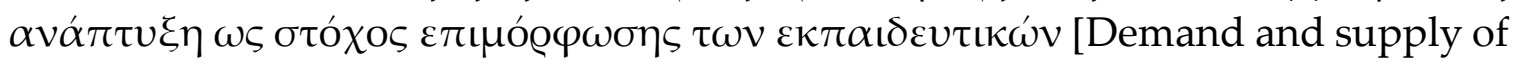
training. Professional development as a goal of teacher training]. In K. Vratsalis (Eds.), Texts for training (pp. 135-155). Athens: Atrapos.

Fukkink RG, Lont A, 2007. Does training matter? A meta-analysis and review of caregiver training studies. Early Childhood Research Quarterly 22: 294-311. Google Scholar

Garet M, Porter A, Desimone L, Birman B, Yoon K, 2001. What makes professional development effective? Analysis of a national sample of teachers. American Education Research Journal 38(4): 915-945. https://journals.sagepub.com/doi/pdf/10.3102/00028312038004915

Gibbons L, Cobb P, 2017. Focusing on Teacher Learning Opportunities to Identify Potentially Productive Coaching Activities. Journal of Teacher Education 68(4): 411-425.

Grammatikopoulos V, Gregoriadis A, Tsigilis N, Zachopoulou E, 2014. Parental conceptions of quality in Greek early childhood education. European Early Childhood Education Research Journal 22 (1): 134-148. 
Grammatikopoulos V, Gregoriadis A, Tsigilis N, Zachopoulou E, 2017. Evaluating quality in early childhood education in relation with children outcomes in Greek context, Early Child Development and Care 188(12): 1816-1825. DOI: 10.1080/03004430.2017. http://dx.doi.org/10.1080/03004430.2017.1289192

Gregoriadis A, Tsigilis N, Grammatikopoulos V, Kouli O, 2016. Comparing quality of childcare and kindergarten centres: the need for a strong and equal partnership in the Greek early childhood education system. Early Child Development and Care 186 (7): 1142-1151.

Guskey TR, 2002a. Professional development and teacher change. Teachers and Teaching: Theory and Practice 8 (3/4): 381-391.

Guskey TR, 2002b. Does it make a difference? Evaluating professional development. Educational Leadership 59(6): 45-51.

Hall J, Sylva K, Melhuish E, Sammons P, Siraj-Blatchford I, Taggart B, 2009. The role of pre-school quality in promoting resilience in the cognitive development of young children. Oxford Review of Education 35(3): 331-352, DOI: 10.1080/03054980902934613. Google Scholar

Hamre B, Hatfield B, Pianta R, Jamil F, 2014. Evidence for general and domain-specific elements of teacher-child interactions: Associations with preschool children's development. Child Development 85: 1257-1274.

Harms T, Clifford MR, Cryer D, 2013. Early Childhood Environment Rating Scale. ECERS-R. (K., Botsoglou, \& D., Kakana, Edit \&Trans.), Thessaloniki, Kyriakidi . (Original work published 1999).

Ho D, Campbell-Barr V, Leeson C, 2010. Quality improvement in early years settings in Hong Kong and England. International Journal of Early Years Education 18: 243258. Google Scholar

Hujala E, Fonsén E, Elo J, 2012. Evaluating the quality of the child care in Finland. Early Child Development And Care 182(3-4). Google Scholar

Hunzicker J, 2011. Effective professional development for teachers: a checklist. Professional Development in Education 37 (2): 177-179.

Karras KG, Oikonomides V, 2015. In - service teachers' education in Greece. In K. G Karras \& C. C. Wolhuter (Eds.), International Handbook of Teacher Education Training \& Re - training Systems in Modern World (pp. 153 - 190). Nicosia: Studies and Publishing.

Kennedy A, 2005. Models of Continuing Professional Development: A framework for analysis. Journal of In-service Education 31(2): 235-50.

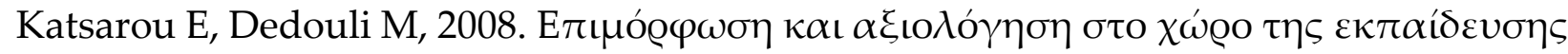
[Training and Evaluation in the field of Education]. Athens: Ministry of EducationPedagogical Institute. schools.gr/programs/epim stelexoi/epim yliko/book5.pdf

Kennedy A, 2014. Understanding continuing professional development: The need for theory to impact on policy and practice. Professional Development in Education 40(5): 688-697. https://doi.org/10.1080/19415257.2014.955122 
Kingston JD, 2017. A Mixed Methods Study: Evaluating the Impact of a Bespoke Professional Development Based on an Analysis of Existing Quality in One Local Authoritys [Unpublished master's thesis]. University College London.

Knight P, 2002. A systemic approach to professional development: Learning as practice. Teaching and Teacher Education 18(3): 229-241. https://doi.org/10.1016/S0742$\underline{051 X(01) 00066-X}$

Korjenevitch M, Dunifon R, 2010. Child care center quality and child development. New York: Cornell University.

Lave J, Wenger E, 1991. Situated Learning: Legitimate Peripheral Participation. Cambridge: Cambridge University Press. http://dx.doi.org/10.1017/CBO9780511815355

Lazzari A, Picchio M, Musatti T, 2013. Sustaining ECEC quality through continuing professional development: systemic approaches to practitioners' professionalization in the Italian context. Early Years 33(2): 133-145. https:/www.tandfonline.com/doi/pdf/10.1080/09575146.2012.758087

Lieberman A, Pointer Mace DH, 2008. Teacher Learning: The Key to Educational Reform. Journal of Teacher Education 59: 226-234.

Lynch RG, 2007. Enriching Children, Enriching the Nation: Public Investment in HighQuality Prekindergarten, Washington, D.C.: Economic Policy Institute. http://www.epi.org/publication/book enriching/

Manning M, Wong GT, Fleming C, Garvis S, 2019. Is teacher qualification associated with the quality of the early childhood education and care environment? A metaanalytic review. Review of Educational Research 89(3): 370-415. https://doi.org/10.3102/0034654319837540

Mashburn AJ, Pianta RC, Hamre BK, Downer JT, Barbarin OA, Bryant D, Burchinal M, Early DM, Howes C, 2008. Measures of classroom quality in prekindergarten and children's development of academic, language, and social skills. Child Development 79 (3): 732-749.

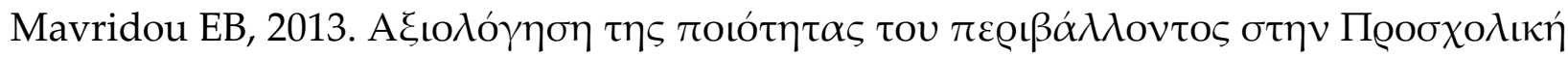

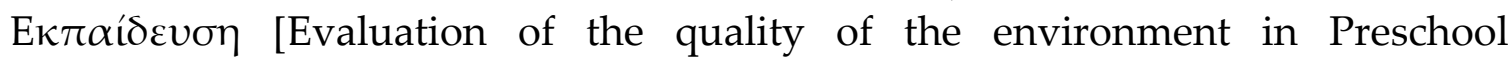
Education]. PhD Thesis, Aristotle University of Thessaloniki. http://ikee.lib.auth.gr/record/133812/files/GRI-2014-11858.pdf

Melhuish E, Ereky-Stevens K, Petrogiannis K, Ariescu A, Penderi E, Rentzou K, Tawell A, Slot P, Broekhuizen M, Leseman P, 2015. A review of research on the effects of Early Childhood Education and Care (ECEC) upon child development. CARE project. Curriculum quality analysis and impact review of European Early Childhood Education and Care (ECEC). (Technical report FP7-SSH-2013-2), European Commission. $\quad \underline{\text { http://ecec- }}$ care.org/fileadmin/careproject/Publications/reports/new version CARE WP4 D 41 Review on the effects of ECEC.pdf Accessed 4 November 2019. 
Miller JA, Bogatova T, 2009. Quality improvements in the early care and education workforce: Outcomes and impact of the T.E.A.C.H. early childhood project. Evaluation and Program Planning 32: 257-277.

Moiduddin E, Aikens N, Tarullo L, West J, Xue Y, 2012.Child outcomes and classroom quality in FACES 2009.OPRE Report 2012-37a, Washington, DC: Office of Planning, Research and Evaluation, Administration for Children and Families, U.S. Department of Health and Human Services. http://www.acf.hhs.gov/sites/default/files/opre/faces 2009.pdf

Moss P, Dahlberg G, 2008. Beyond Quality in Early Childhood Education and CareLanguages of Evaluation. New Zealand Journal of Teachers' Work 5(1): 3- 12.

National Professional Development Center on Inclusion (NPDCI), 2008. What do we mean by professional development in the early childhood field? Chapel Hill, NC: The University of North Carolina, FPG Child Development Institute, National Professional Development Center on Inclusion (NPDCI). https://npdci.fpg.unc.edu/sites/npdci.fpg.unc.edu/files/resources/NPDCI Profess ionalDevelopmentInEC 03-04-08 0.pdf

OECD, 2018. Education at a Glance 2018: OECD Indicators. OECD Publishing, Paris. http://dx.doi.org/10.1787/eag-2018-en

Patton K, Parker M, 2017. Teacher education communities of practice: More than a culture of collaboration. Teaching and Teacher Education 67: 351-360.

Peeters J, Cameron, C, Lazzari A, Peleman B, Budginaite I, Hauari H, Siarova H, 2014. Impact of continuous professional development and working conditions of early childhood education and care practitioners on quality, staff-child interactions and children's outcomes: A systematic synthesis of research evidence. Gent: VBJK. http://www.charlotte-buehler-institut.at/wp-content/uploads/2016/07/Impact-ofCPD-and-WC-Final-Report-October-2014.pdf

Pelema, B, Lazzari A, Budginaite I, Siarova H, Hauari H, Peeters J, Cameron C, 2018. Continuous professional development and ECEC quality: Findings from a European systematic literature review. European Journal of Education 53(1): 9-22. https://doi.org/10.1111/ejed.12257

Petrogiannis K, 2002. Greek Day Care Centers Quality, Caregivers Behavior and Children's Development. International Journal of Early Years Education 10(2): 138-146.

Petrogiannis K, 2010. Early childhood care and education in Greece: Some facts on research and policy. International Journal of Early Childhood 42 (2): 131-139.

Rentzou K, 2012. Quality of care and education provided by Greek day care centers: An approach from researcher's and early childhood educators' perspective. Early Child Development and Care 182(10): 1335-1348. https://doi.org/10.1080/03004430.2011.615927

Roach MA, Riley D, Adams D, Edie D, 2005. Evaluation of a State Initiative to Improve Child Care Quality. Early Education and Development 16(1): 69-84. https://doi.org/10.1207/s15566935eed1601 5 
Schachter RE, 2015. An Analytic Study of the Professional Development Research in Early Childhood Education. Early Education and Development 26(8): 10571085. DOI: $10.1080 / 10409289.2015 .1009335$

Sheridan S, 2001. Pedagogical Quality in Preschool. An issue of perspectives. PhD Thesis, University of Gothenburg. https://gupea.ub.gu.se/handle/2077/10307

Sheridan S, Giota J, Han YM, Kwon JY, 2009. A cross-cultural study of preschool quality in South Korea and Sweden: ECERS evaluations. Early Childhood Research Quarterly 24(2): 142-156

Sheridan S, Edwards C, Marvin CA, Knoche LL, 2009. Professional Development in Early Childhood Programs: Process Issues and Research Needs. Early Education and Development 20(3):377-401. DOI: 10.1016/j.ecresq.2009.03.004 Google Scholar

Siraj I, Kingston D, Neilsen-Hewett C, Howard S, Melhuish E, de Rosnay M, Duursma E, Luu B, 2016. Fostering Effective Early Learning: A review of the current international evidence considering quality in early childhood education and care programmes - in delivery, pedagogy and child outcomes, Sydney, Australia: NSW Department of Education. https://ro.uow.edu.au/cgi/viewcontent.cgi?article=5315\&context=sspapers

Slot P, 2018. "Structural characteristics and process quality in early childhood education and care: A literature review". OECD Education Working Papers, No. 176, OECD Publishing, Paris.

Sylva K, Melhuish E, Sammons P, Siraj-Blatchford I, Taggart B, 2010. Early childhood matters: Evidence from the effective pre-school and primary education project. Abingdon: Routledge. Google Scholar Accessed 13 January 2020.

Sylva K, Melhuish E, Sammons P, Siraj-Blatchford I, Taggart B, 2011. Pre-school quality and educational outcomes at age 11: Low quality has little benefit. Journal of Early Childhood Research 9(2): 109-124. Google Scholar

Sylva K, Melhuish E, Sammons P, Siraj I, Taggart B, Smees R, Toth K, Welcomme W, Hollingworth K, 2014. Students' Educational and Developmental Outcomes at age 16. Effective Pre-school, Primary and Secondary Education EPPSE 3-16 project, London, DfE. Google Scholar

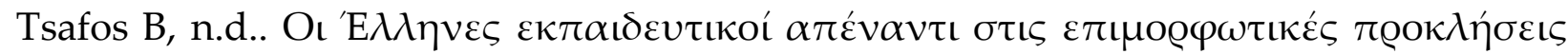
[Greek teachers face the educational challenges]. Proceedings of the Symposium organized by the 3rd Office of the Board of Directors Athens. http://www.actionresearch.gr/system/files/keimena/Keimena09 Accessed 17 May 2019.

UNESCO 2014. EFA Global Monitoring Report 2013/14 - Teaching and Learning: Achieving Quality for All. Paris: UNESCO. https://unesdoc.unesco.org/ark:/48223/pf0000225654 Accessed 2 Mars 2018.

UNESCO 2015. EDUCATION FOR ALL 2000-2015: achievements and challenges. Paris: UNESCO.https://en.unesco.org/gem-report/report/2015/education-all-2000-2015achievements-and-challenges Accessed 2 Mars 2018. 
Yoon KS, Duncan T, Lee SW, Scarloss B, Shapley KL, 2007. Reviewing the evidence on how teacher professional development affects student achievement (Issues \& Answers report, REL 2007-No. 033), Washington, DC: U.S. Department of Education, Institute of Education Sciences, National Center for Education Evaluation and Regional Assistance, Regional Educational Laboratory Southwest. Vandell DL, Belsky J, Burchinal M, Steinberg L, Vandergrift N, 2010. Do effects of early child care extend to age 15 years? results from the NICHD study of early child care and youth development. Child Development 81(3): 737-756. Google Scholar

Van Driel JH, Meirink JA, van Veen K, Zwart RC, 2012. Current trends and missing links in studies on teacher professional development in science education: a review of design features and quality of research. Studies in Science Education 48(2): 129160. https://doi.org/(...)03057267.2012.738020

Wenger E, 2006. Communities of practice. A brief introduction. https://www.semanticscholar.org/paper/Communities-of-Practice\%3A-A-BriefIntroduction-Wenger/a93df11e3ae4a54850b1c0ec0a2455059457e31f Accessed 23 April 2018

Whitebook M, 2003. Early Education Quality: Higher teacher qualifications for better learning environments - A review of the literature. Berkeley, CA: Center for the Study of Child Care Employment. Google Scholar 

to copy, distribute, transmit or adapt the article content, providing a proper, prominent and unambiguous attribution to the authors in a manner that makes clear that the materials are being reused under permission of a Creative Commons License. Views, opinions and conclusions expressed in this research article are views, opinions and conclusions of the author(s). Open Access Publishing Group and European Journal of Education Studies shall not be responsible or answerable for any loss, damage or liability caused in relation to/arising out of conflicts of interest, copyright violations and inappropriate or inaccurate use of any kind content related or integrated into the research work. All the published works are meeting the Open Access Publishing requirements and can be freely accessed, shared, modified, distributed and used in educational, commercial and non-commercial purposes under a Creative Commons Attribution 4.0 International License (CC BY 4.0). 